Research

\title{
Microcirculatory changes and skeletal muscle oxygenation measured at rest by non-infrared spectroscopy in patients with and without diabetes undergoing haemodialysis
}

\author{
Roberto Alberto De Blasi ${ }^{1}$, Remo Luciani², Giorgio Punzo ${ }^{2}$, Roberto Arcioni ${ }^{1}$, Rocco Romano ${ }^{3}$, \\ Marta Boezi ${ }^{1}$ and Paolo Menè ${ }^{2}$
}

\begin{abstract}
1'Department of Anaesthesiology and Intensive Care, II Faculty of Medicine University 'La Sapienza', Via di Grottarossa 1035, 00189 Rome, Italy 2Department of Nephro-Urology, II Faculty of Medicine University 'La Sapienza', Via di Grottarossa 1035, 00189 Rome, Italy

${ }^{3}$ Department of Neuroscience, Marche University Politecnica, Via Tronto 10/A, 60100 Ancona, Italy
\end{abstract}

Corresponding author: Roberto Alberto De Blasi, radbl@libero.it

Published: 30 November 2009

This article is online at http://ccforum.com/content/13/S5/S9

(c) 2009 BioMed Central Ltd
Critical Care 2009, 13(Suppl 5):S9 (doi:10.1186/cc8007)

\begin{abstract}
Introduction: Haemodialysis has direct and indirect effects on skin and muscle microcirculatory regulation that are severe enough to worsen tolerance to physical exercise and muscle asthenia in patients undergoing dialysis, thus compromising patients' quality of life and increasing the risk of mortality. In diabetes these circumstances are further complicated, leading to an approximately sixfold increase in the incidence of critical limb ischaemia and amputation. Our aim in this study was to investigate in vivo whether haemodialysis induces major changes in skeletal muscle oxygenation and blood flow, microvascular compliance and tissue metabolic rate in patients with and without diabetes.

Methods: The study included 20 consecutive patients with and without diabetes undergoing haemodialysis at Sant Andrea University Hospital, Rome from March to April 2007. Near-infrared spectroscopy (NIRS) quantitative measurements of tissue haemoglobin concentrations in oxygenated $\left[\mathrm{HbO}_{2}\right]$ and deoxygenated forms $[\mathrm{HHb}]$ were obtained in the calf once hourly for 4 hours during dialysis. Consecutive venous occlusions allowed one to obtain muscular blood flow (mBF), microvascular compliance and muscle oxygen consumption $\left(\mathrm{mVO}_{2}\right)$. The tissue oxygen saturation $\left(\mathrm{StO}_{2}\right)$ and content $\left(\mathrm{CtO}_{2}\right)$ as well as the microvascular bed volume were derived from the haemoglobin concentration. Nonparametric tests were used to compare data within each group and among the groups and with a group of 22 matched healthy controls.

Results: The total haemoglobin concentration and $[\mathrm{HHb}]$ increased significantly during dialysis in patients without and with diabetes. Only in patients with diabetes, dialysis involved a $\left[\mathrm{HbO}_{2}\right], \mathrm{CtO}_{2}$ and $\mathrm{mVO}_{2}$ increase but left $\mathrm{StO}_{2}$ unchanged. Multiple regression analysis disclosed a significant direct correlation of $\mathrm{StO}_{2}$ with $\mathrm{HbO}_{2}$ and an inverse correlation with $\mathrm{mVO}_{2}$. Dialysis increased mBF only in diabetic patients. Microvascular compliance decreased rapidly and significantly during the first hour of dialysis in both groups.

Conclusions: Our NIRS findings suggest that haemodialysis in subjects at rest brings about major changes in skeletal muscle
\end{abstract}

oxygenation, blood flow, microvascular compliance and tissue metabolic rate. These changes differ in patients with and without diabetes. In all patients haemodialysis induces changes in tissue haemoglobin concentrations and microvascular compliance, whereas in patients with diabetes it alters tissue blood flow, tissue oxygenation $\left(\mathrm{CtO}_{2},\left[\mathrm{HbO}_{2}\right]\right)$ and the metabolic rate $\left(\mathrm{mVO}_{2}\right)$. In these patients the $\mathrm{mVO}_{2}$ is correlated to the blood supply. The effects of haemodialysis on cell damage remain to be clarified. The absence of $\mathrm{StO}_{2}$ changes is probably linked to an opposite $\left[\mathrm{HbO}_{2}\right]$ and $\mathrm{mVO}_{2}$ pattern.

\section{Introduction}

Knowing how haemodialysis influences skeletal muscle circulation is of clinical importance given the growing evidence suggesting that the microcirculation has a key role in worsening tolerance to physical exercise in patients undergoing dialysis $[1,2]$.

Muscle asthenia is among the complications of dialysis that can compromise patient quality of life [3]. The decreased aerobic capacity that ensues when muscle dysfunction impairs patients' ability to carry out the normal activities of everyday life is associated with an increased risk of mortality [4], suggesting that physical training could lengthen the life expectancy of patients with chronic renal failure [2].

Despite numerous studies investigating the various features of muscle dysfunction during dialysis, none have yet identified a single, proven causative factor.

The possibility that muscle symptoms depend on altered microcirculatory oxygen transport and functionality receives

$\mathrm{CtO}_{2}=$ tissue oxygen content; $\mathrm{Hb}=$ haemoglobin; $\left[\mathrm{HbO}_{2}\right]=$ oxygenated tissue haemoglobin concentration; $[\mathrm{HbT}]=$ total haemoglobin concentration; $[\mathrm{HHb}]=$ deoxygenated tissue haemoglobin concentration; $\mathrm{mBF}=$ muscular blood flow; $\mathrm{mHF}=$ muscular haemoglobin flow; $\mathrm{mVO}_{2}=$ muscle oxygen consumption; NIRS $=$ near-infrared spectroscopy; $\mathrm{StO}_{2}=$ tissue oxygen saturation. 
support from several observations, including reduced capillary density in muscle tissue $[2,5]$, diminished vasodilator response to post-ischaemia reperfusion $[6,7]$ and impaired endothelium-dependent vasodilation $[8,9]$. The most commonly used non-invasive technique that can also be used clinically at the bedside for directly assessing microvascular dysfunction and skeletal muscle oxygenation is near-infrared spectroscopy (NIRS) [10].

Some evidence nevertheless suggests that dialysis-induced changes in muscle exercise performance depend exclusively on reduced mitochondrial oxidative capacity without a defect in oxygen transport [1].

In diabetes, the circumstances are further complicated by the typical diabetic changes [11] that frequently lead to endstage renal disease. In patients with diabetes, haemodialysis can bring about a sixfold increase in the incidence of critical limb ischaemia and amputation. Major lower-extremity amputation is especially likely in the first 12 months after patients start renal replacement therapy $[12,13]$.

Although previous studies have investigated changes in systemic haemodynamics [14] and forearm blood flow [15] during hemodialysis, few and only indirect studies have assessed in vivo dialysis-induced changes in the muscle tissue. This information might help to explain how dialysis acts on muscle tissue and why muscular performance worsens in patients undergoing dialysis.

Our primary aim in the present in vivo study in humans was to determine whether haemodialysis brings about major changes in skeletal muscle oxygenation and blood flow, in microvascular compliance (the ability of small blood vessels in muscle tissue to dilate) and in the tissue metabolic rate measured at rest. We also wanted to investigate possible physiological interactions between these four variables during haemodialysis, and to identify differences in the patterns of change in these tissue variables during haemodialysis in patients with and without diabetes.

Our secondary aim was to detect differences in baseline variables in patients with and without diabetes and in healthy subjects. We non-invasively assessed the calf-muscle haemoglobin $(\mathrm{Hb})$ concentration (total and fractional $\mathrm{Hb}$ concentration, oxygenated tissue haemoglobin concentration $\left.\left[\mathrm{HbO}_{2}\right]\right)$, tissue oxygen saturation $\left(\mathrm{StO}_{2}\right)$ and tissue oxygen content $\left(\mathrm{CtO}_{2}\right)$, blood flow and muscle oxygen consumption $\left(\mathrm{mVO}_{2}\right)$ simultaneously by NIRS in the two groups (patients with diabetes and patients without diabetes) before haemodialysis and hourly for 4 hours.

\section{Materials and methods}

\section{Selection of subjects}

The study was conducted at Sant Andrea Hospital, Rome from March to April 2007. The study protocol was approved by the hospital Anesthesia and Intensive Care Medicine Department and Dialysis Unit Institutional Review Board, and informed consent was obtained from each participant. We enrolled 20 consecutive patients from the Dialysis Unit, selecting those with a 5-year history of end-stage renal disease who had never changed their treatment modality, who had received similar dialytic treatment (see Haemodialysis management), who had required no hospitalizations in the month before the study and who had no signs of infections or other diseases. All patients had undergone regular cardiogical follow-up with 6-monthly electrocardiograms and echocardiograms when necessary.

Patients younger than 18 years and older than 80 years of age were excluded. We also excluded patients who had a history of autonomic nervous system dysfunction or who experienced hypotensive episodes during dialysis. Further exclusion criteria were patients with lower-limb changes likely to interfere with NIRS readings (marked oedema, abundant subcutaneous fat, varicose veins, diabetic ulcers, and traumatic or surgical scars), patients with cardiac insufficiency (New York Health Association class III or IV) or moderate or severe chronic obstructive pulmonary disease, or both, and patients who were unable to tolerate the venous occlusion procedures foreseen in the study protocol.

Routine monitoring included the intravascular $\mathrm{Hb}$ content, pulse oximetry, non-invasive blood pressure measurement, body weight $(\mathrm{kg})$, and gastrocnemius muscle skinfold thickness. The blood pressure and heart rate were recorded during each dialysis session every 30 minutes.

Patients were sequentially enrolled and assigned to one of two groups according to the presence or absence of insulintreated diabetes: patients with diabetes $(n=10)$ and patients without diabetes $(n=10)$. As a control group to compare baseline values, we enrolled 22 healthy subjects who had taken part in an earlier study.

\section{Haemodialysis management}

All patients received erythropoietin in intravenous boluses of 2,000 to 15,000 units three times a week as well as oral or intravenous iron supplementation for at least 2 months before the study. All patients underwent haemodialysis three times a week according to a standardized technique. The weekly measure of dialysis adequacy - calculated as the product of urea clearance and dialysis time divided by the body water content $(\mathrm{Kt} / \mathrm{V})$ - for the preceding month was $>1.2$. All patients received bicarbonate-based haemodialysis with ultrafiltration using a distal arteriovenous shunt. The dialysate rate was $500 \mathrm{ml} /$ minute and blood flow was maintained at $300 \mathrm{ml} /$ minute. All patients were dialyzed with the same machine (Integra; Hospal, Zaventem Belgium). Polysulphone dialysers were used in all patients with an effective membrane area of 1.6 to $1.8 \mathrm{~m}^{2} \mathrm{~F} 7 \mathrm{HPS}$ and F8 HPS low flux (Fresenius Medical Care, Bad Homburg, Germany). The dialysate 


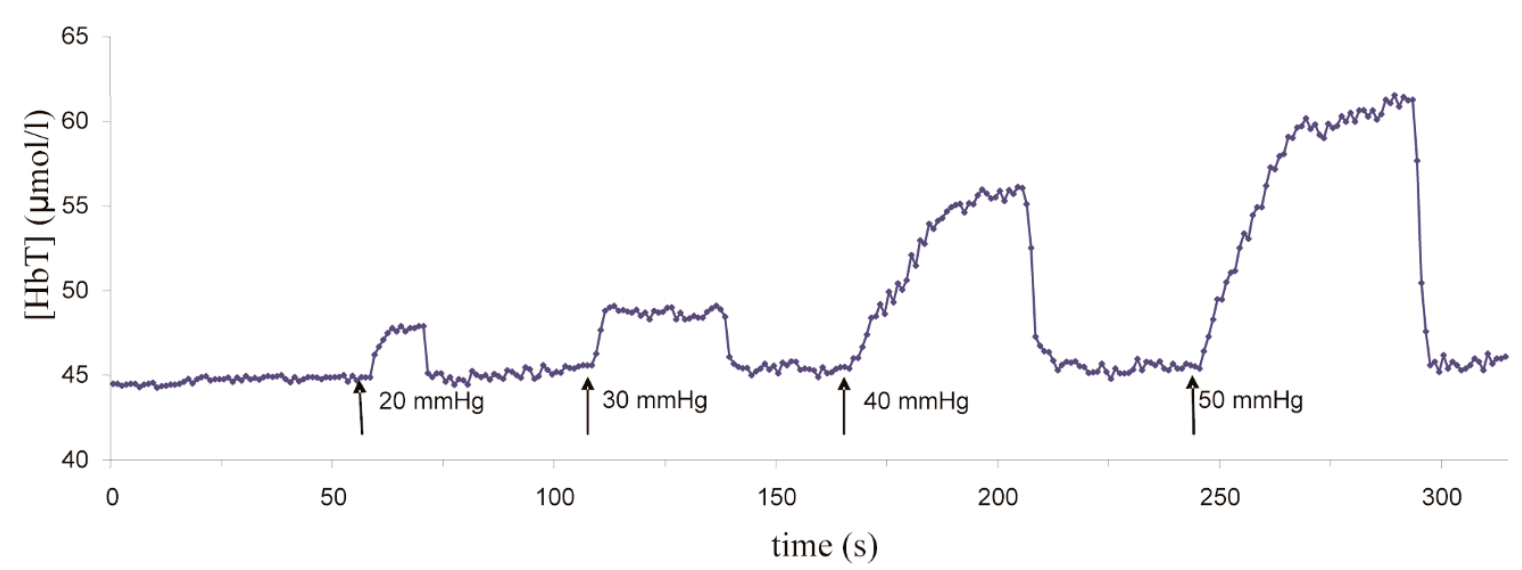

Total haemoglobin concentration variation during consecutive venous occlusion. Representative trace of total haemoglobin concentration [HbT] changes during four consecutive venous occlusions at different pneumatic cuff inflation pressures.

consisted of potassium $2.0 \mathrm{mmol} / \mathrm{l}$, calcium $1.5 \mathrm{mmol} / \mathrm{l}$, bicarbonate $32 \mathrm{mmol} / \mathrm{l}$, magnesium $0.5 \mathrm{mmol} / \mathrm{l}$, acetate $3.0 \mathrm{mmol} / \mathrm{l}$, and glucose $1.0 \mathrm{~g} / \mathrm{l}$. The dialysate temperature was kept at $36^{\circ} \mathrm{C}$ to maintain haemodynamic stability [16].

\section{Near-infrared spectroscopy data collection}

Before haemodialysis began, an NIRS probe (NIMO-4 tissue probe; Nirox srl, Brescia, Italy) was placed and secured with an elastic band along the lateral side of the calf (lateral gastrocnemius muscle), taking care not to apply it over possible haematomas or along the course of visible veins. To avoid hampering venous return the leg was kept with the thigh on a level with the heart and the foot raised by about $10 \mathrm{~cm}$. Two pneumatic cuffs were attached around the thigh and the ankle, and were connected to an automatic inflation system (Hokanson E20 Rapid Cuff Inflator and AG101 Cuff Inflator Air Source, PMS Instruments Ltd, Maidenhead, Berkshire, UK) capable of reaching a predefined pressure in less than 0.5 seconds. To avoid the possible interference of ambient light on NIRS measurements, the whole leg was wrapped in a black cloth. Just before applying the probe, the calf skinfold thickness was measured using a skinfold caliper (Gima SpA, Gessate, Milan, Italy).

One set of NIRS measurements was recorded once hourly for 4 hours during dialysis. The first measurement set was defined as predialysis, whereas the ensuing sets were measured at the beginning of the second hour, the third hour and the fourth hour of dialysis. Three consecutive pneumatic cuff inflation pressures at $30 \mathrm{mmHg}, 40 \mathrm{mmHg}$, and $50 \mathrm{mmHg}$ - or, in patients with diastolic pressures $<50 \mathrm{mmHg}$, a maximum value equal to the diastolic pressure minus $10 \mathrm{mmHg}$ - were maintained for about 50 seconds (venous occlusion) with 10 seconds between compressions (Figure 1). The baseline recording was continued during the interval between compressions until the next hour when subjects underwent venous compressions again. All data recorded were stored on a laptop computer for offline analysis.

\section{Near-infrared spectrometer}

The $\mathrm{Hb}$ concentrations were quantified with a commercially available continuous-wave tissue oxymeter (NIMO; Nirox srl, Brescia, Italy), as detailed elsewhere [17,18]. The oximeter measures the absolute tissue $\left[\mathrm{HbO}_{2}\right]$ and deoxygenated tissue haemoglobin concentration [HHb] from the light absorption spectrum at a wavelength of $980 \mathrm{~nm}$ that corresponds to maximal optical absorption of water within the tissue. To account for the possible influence of the subcutaneous fat layer on NIRS [19], we also applied a real-time correction using an algorithm included in the software program version 2.0 supplied with the spectrometer. The correlation coefficients used for the algorithm were obtained by applying a two-layered analytical model [20] using absorption and scattering coefficients of the fat layer for wavelengths of interest obtained from the literature [21]. The measurement of the subcutaneous two-layered fat by skinfold anthropometry is a widely used and valid technique to estimate the muscular mass of subjects with chronic renal disease [22].

\section{Offline data processing}

All recorded tracks were visually inspected: a venous occlusion was determined as satisfactory for further analysis if the baseline track remained steady before occlusion, then oxyhaemoglobin and deoxyhaemoglobin rose during the occlusion, returning to a similar baseline level after the occlusion was released. Data were analysed offline with the software program supplied with the NIMO oximeter (Nimo Data Analysis v2.0; Nirox srl).

The variables measured by NIRS are presented in Table 1. 
Table 1

\begin{tabular}{|c|c|c|c|}
\hline Abbreviation & Full name & Units & Type of measurement \\
\hline$\left[\mathrm{HbO}_{2}\right]$ & Oxygenated haemoglobin concentration & $\mu \mathrm{mol} / \mathrm{l}$ & Direct \\
\hline$[\mathrm{HHb}]$ & Deoxygenated haemoglobin concentration & $\mu \mathrm{mol} / \mathrm{l}$ & Direct \\
\hline$[\mathrm{HbT}]$ & Total haemoglobin concentration & $\mu \mathrm{mol} / \mathrm{l}$ & Calculated \\
\hline $\mathrm{StO}_{2}$ & Tissue oxygen saturation & $\%$ & Calculated \\
\hline $\mathrm{CtO}_{2}$ & Tissue oxygen content & $\mathrm{ml} \mathrm{O}_{2} / 100 \mathrm{ml}$ & Calculated \\
\hline Compliance & Microvascular compliance & $\mathrm{ml} / \mathrm{mmHg} / 100 \mathrm{ml}$ & Calculated \\
\hline $\mathrm{mHF}$ & Muscular haemoglobin flow & $\mu \mathrm{mol} / \mathrm{min} / 100 \mathrm{ml}$ & Calculated \\
\hline $\mathrm{mBF}$ & Muscular blood flow & $\mathrm{ml} / \mathrm{min} / 100 \mathrm{ml}$ & Calculated \\
\hline $\mathrm{mVO}_{2}$ & Muscle oxygen consumption & $\mathrm{ml} / \mathrm{min} / 100 \mathrm{ml}$ & Calculated \\
\hline
\end{tabular}

The spectrophotometer directly measured $\left[\mathrm{HbO}_{2}\right]$ and the haemoglobin concentration; $\mathrm{StO}_{2}$ was obtained automatically from the ratio of $\left[\mathrm{HbO}_{2}\right]$ to the total haemoglobin concentration $[\mathrm{HbT}]$. Blood flow was measured in two ways. Because oxygen delivery depends closely on the $\mathrm{Hb}$ flow and because capillary and arteriolar haematocrit are significantly lower than systemic haematocrit [23], we measured the linear increase in $[\mathrm{HbT}]$ within the first 20 seconds of a $40 \mathrm{mmHg}$ venous occlusion, expressed in micromoles per $100 \mathrm{ml}$ tissue per minute $[24,25]$ - muscular haemoglobin flow (mHF). We also calculated muscular blood flow (mBF), expressed in millilitres of blood/100 ml per minute, converting the [HbT] changes during venous occlusion to millilitres of blood per $100 \mathrm{ml}$ tissue per minute using the $\mathrm{Hb}$ content obtained from blood samples drawn at each hour.

Microvascular compliance was calculated as the [HbT] changes at different venous occlusion pressures and expressed as millilitres of blood increase in $100 \mathrm{ml}$ tissue per change in pressure $(\mathrm{mmHg})$, converting the $[\mathrm{HbT}]$ to millilitres using the $\mathrm{Hb}$ blood content as previously described [10]. The $[\mathrm{HbT}]$ values were collected approximately 30 to 40 seconds after each cuff inflation at the plateau phase when superficial, deep, and other small vessels were assumed to be fully distended. Compliance curves were obtained by plotting the relationship between cuff pressure and $[\mathrm{HbT}]$. These values were expressed in millilitres of blood per $\mathrm{mmHg}$ taking into account the vascular $\mathrm{Hb}$ content. The $\mathrm{CtO}_{2}$ (expressed in millilitres of oxygen per $100 \mathrm{ml}$ tissue) was calculated considering the fractional $\mathrm{StO}_{2},[\mathrm{HbT}]$ (expressed in grams), and the millilitres of oxygen bound by $1 \mathrm{~g} \mathrm{Hb}\left(1.36 \mathrm{ml} \mathrm{O}_{2} / \mathrm{g}\right.$ $\mathrm{HbT}$ ) [10].

The $\mathrm{mVO}_{2}$ was measured during venous occlusion as the initial linear increase in $\mathrm{Hb}$ concentration, after subtracting the $\mathrm{Hb}$ concentration increase from arterial blood [24].
The data obtained were compared with those for the 22 matched healthy control subjects. Because the spectroscopy measurements cannot distinguish whether the dialysis-induced variations of tissue $\mathrm{Hb}$ concentration are related to the intravascular increase of $\mathrm{Hb}$ concentration or to the increase of the vascular bed, a percentage corresponding to the rate of the hourly haematocrit changes has been substracted from the hourly changes of tissue $\mathrm{Hb}$ concentration. This correction was aimed to better show the importance of tissue $[\mathrm{HbT}]$ and its derived variables $\left(\mathrm{CtO}_{2}\right.$ and microvascular compliance), changes related to vascular bed variations. The corrected data obtained are reported in Table 2 and the statistical significance is given in the Results section.

\section{Statistical analysis}

The results are expressed as the mean \pm standard deviation. The data were analysed with SPSS version 13.0 and Med Calc Version 9.4.2.0 for Windows. Nonparametric tests were used to compare data - the Friedman test and the Wilcoxon test were used to compare data within each group, and the Mann-Whitney $U$ test was used to compare data among the two groups and healthy controls. Spearman's rank correlation coefficient with a discriminant $P<0.05$ was used to identify significant correlations between the variables measured during dialysis.

\section{Results}

All 20 patients enrolled completed the study. All of these patients tolerated NIRS measurements and manoeuvres for vascular occlusion. The percentage of tracks discarded because of their unreliability was $10 \%$. Patient ages ranged from 44 to 77 years. No differences were found between the groups of subjects for age, thickness of subcutaneous fat, vascular $\mathrm{Hb}$ content, and diastolic and systolic arterial pressures. Conversely, the body weight differed between the patients with diabetes and the other subjects (Table 3 ). Mean 
Table 2

Data corrected for possible variations in total haemoglobin concentration related to dialysis-induced fluid removal

\begin{tabular}{|c|c|c|c|c|c|c|c|c|}
\hline \multirow[b]{2}{*}{ Variable } & \multicolumn{4}{|c|}{ Patients without diabetes $(n=10)$} & \multicolumn{4}{|c|}{ Patients with diabetes $(n=10)$} \\
\hline & TO & $\mathrm{T} 1$ & $\mathrm{~T} 2$ & T3 & TO & $\mathrm{T} 1$ & $\mathrm{~T} 2$ & T3 \\
\hline $\begin{array}{l}\text { Total haemoglobin } \\
\text { concentration }(\mu \mathrm{M} / \mathrm{l})\end{array}$ & $\begin{array}{c}46.62^{\mathrm{a}} \pm \\
18.44\end{array}$ & $\begin{array}{c}56.33 \pm \\
17.05\end{array}$ & $\begin{array}{c}56.44 \pm \\
17.38\end{array}$ & $\begin{array}{c}56.25 \pm \\
17.69\end{array}$ & $\begin{array}{l}45.17^{\mathrm{a}} \pm \\
17.43\end{array}$ & $\begin{array}{c}58.33 \pm \\
21.40\end{array}$ & $\begin{array}{l}59.61 \pm \\
22.75\end{array}$ & $\begin{array}{c}66.53 \pm \\
23.51\end{array}$ \\
\hline $\begin{array}{l}\text { Tissue oxygen content } \\
\left(\mathrm{ml} \mathrm{O} \mathrm{O}_{2} / 100 \mathrm{ml}\right)\end{array}$ & $\begin{array}{l}0.18 \pm \\
0.10\end{array}$ & $\begin{array}{l}0.23 \pm \\
0.09\end{array}$ & $\begin{array}{c}0.20 \pm \\
0.13\end{array}$ & $\begin{array}{c}0.21 \pm \\
0.12\end{array}$ & $\begin{array}{c}0.20^{\mathrm{a}} \pm \\
0.10\end{array}$ & $\begin{array}{l}0.24 \pm \\
0.13\end{array}$ & $\begin{array}{c}0.26^{c} \pm \\
0.14\end{array}$ & $\begin{array}{c}0.32 \pm \\
0.20\end{array}$ \\
\hline $\begin{array}{l}\text { Microvascular compliance } \\
(\mu \mathrm{M} / \mathrm{mmHg})\end{array}$ & $\begin{array}{c}0.153^{\mathrm{a}} \pm \\
0.109\end{array}$ & $\begin{array}{c}0.049^{b} \pm \\
0.035\end{array}$ & $\begin{array}{c}0.010 \pm \\
0.007\end{array}$ & $\begin{array}{c}0.004 \pm \\
0.001\end{array}$ & $\begin{array}{c}0.203^{\mathrm{a}} \pm \\
0.150\end{array}$ & $\begin{array}{c}0.039 \pm \\
0.058\end{array}$ & $\begin{array}{c}0.016 \pm \\
0.017\end{array}$ & $\begin{array}{c}0.013 \pm \\
0.010\end{array}$ \\
\hline
\end{tabular}

To take into account possible total haemoglobin concentration variations related to dialysis-induced fluid removal, the near-infrared spectroscopy total haemoglobin concentration values and related variables (tissue oxygen content, and compliance) were corrected for vascular haemoglobin changes during dialysis. T0, predialysis. The statistical analysis was performed with the Wilcoxon test, considering $P<0.05$ significant: a $P<0.05$ vs. beginning of the second hour (T1), beginning of the third hour (T2), beginning of the fourth hour (T3); ${ }^{b} P<0.05$ vs. T2, T3; ${ }^{c} P<0.05$ vs. T3.

overall weight loss was similar in the two groups and diminished significantly by hour during dialysis (Table 4). Of the 20 patients studied, 12 were anuric and eight had a low glomerular filtration rate ( 1 to $9 \mathrm{ml} /$ minute). Of the 10 nondiabetic patients, three were normotensive and were not receiving vasoactive drugs.

\section{Cardiovascular function}

All of the patients studied showed good haemodynamic stability during dialysis, and no hypotensive episodes developed.

\section{Total haemoglobin concentration}

Predialysis $[\mathrm{HbT}]$ values in the patients studied almost matched those in healthy subjects (Table 4). In the nondiabetic patients as well as in the diabetic patients, [HbT] increased significantly from baseline during dialysis (Friedman test, $P=0.002$ and $P=0.001$ ). No significant difference was found between groups.

At all timepoints, these increases remained statistically unchanged when we corrected our subjects' [HbT] values for vascular $\mathrm{Hb}$ concentrations during dialysis (Table 2) suggesting that dialysis-induced fluid removal has no influence on the $[\mathrm{HbT}]$ increase.

\section{Deoxygenated tissue haemoglobin concentration}

Predialysis $[\mathrm{HHb}]$ values in the patients studied also matched those in healthy control subjects (Table 4). During dialysis, $[\mathrm{HHb}]$ increased in both groups of patients (Friedman test, $P=0.001$ ). No differences were found between groups.

\section{Oxygenated haemoglobin concentration}

Predialysis $\left[\mathrm{HbO}_{2}\right]$ values were approximately $36 \%$ lower in patients with and without diabetes than in healthy subjects (Table 4). In patients with diabetes, $\left[\mathrm{HbO}_{2}\right]$ increased during dialysis (Friedman test, $P=0.017$ ); conversely, in patients without diabetes, dialysis left $\left[\mathrm{HbO}_{2}\right]$ values unchanged.

\section{Muscular blood flow}

In patients without diabetes, the $\mathrm{mHF}$ and $\mathrm{mBF}$ remained unchanged during dialysis (Table 4) - whereas in those patients with diabetes, the $\mathrm{mHF}$ and $\mathrm{mBF}$ increased only after 2 hours of dialysis. After dialysis for 2 hours, these variables remained statistically unchanged.

\section{Microvascular compliance}

Predialysis microvascular compliance values were similar in patients without diabetes and in healthy subjects, whereas they were higher in diabetic patients (Table 4). In both groups of patients studied, compliance decreased rapidly and significantly during the first hour of dialysis, with a more pronounced decrease in patients with diabetes (Friedman test, $P=0.003$ ). Thereafter, in both groups of patients compliance diminished further during the whole dialysis.

When we corrected data for vascular $\mathrm{Hb}$ concentration changes, the differences in compliance remained statistically unchanged (Table 2).

\section{Tissue oxygen content}

Predialysis $\mathrm{CtO}_{2}$ values were $38 \%$ and $34 \%$ lower in patients without and with diabetes than in healthy control subjects (Table 4). In patients without diabetes, the $\mathrm{CtO}_{2}$ remained statistically unchanged during dialysis - whereas the $\mathrm{CtO}_{2}$ increased in patients with diabetes (Friedman test, $P=0.01$ ), approaching values similar to those measured in healthy subjects. The same pattern was observed for the $\mathrm{CtO}_{2}$ values corrected by the vascular $\mathrm{Hb}$ changes (Table 2).

\section{Tissue oxygen saturation}

Predialysis $\mathrm{StO}_{2}$ values were similar in both groups of patients and in healthy subjects. During haemodialysis, $\mathrm{StO}_{2}$ values remained unchanged. No significant differences were found between the two groups. 
Table 3

\begin{tabular}{|c|c|c|c|c|}
\hline Anthropometric data & $\begin{array}{l}\text { Healthy subjects } \\
\quad(n=22)\end{array}$ & $\begin{array}{l}\text { Patients without diabetes } \\
\qquad(n=10)\end{array}$ & $\begin{array}{l}\text { Patients with diabetes } \\
\qquad(n=10)\end{array}$ & $P$ value \\
\hline Age (years) & $56.8 \pm 9.3$ & $57.8 \pm 11.5$ & $60.1 \pm 10.1$ & ns \\
\hline Gender (male/female) & $17 / 5$ & $7 / 3$ & $6 / 4$ & ns \\
\hline Height $(\mathrm{cm})$ & $169.7 \pm 8.1$ & $169.7 \pm 6.2$ & $165.6 \pm 1.7$ & ns \\
\hline Subcutaneous fat layer (mm) & $7.0 \pm 2.3$ & $6.5 \pm 1.6$ & $7.6 \pm 1.0$ & ns \\
\hline Baseline weight (kg) & $77.3 \pm 13.4$ & $74.9 \pm 18.8$ & $93.8 \pm 24.1^{*}$ & 0.048 \\
\hline \multicolumn{5}{|l|}{ Systemic vascular variables } \\
\hline Haemoglobin vascular (g/dl) & $13.9 \pm 0.9$ & $12.3 \pm 1.81$ & $11.9 \pm 1.9$ & ns \\
\hline Systolic arterial pressure $(\mathrm{mmHg})$ & $136.6 \pm 15.4$ & $148.8 \pm 21.5$ & $160.1 \pm 15.7$ & ns \\
\hline Diastolic arterial pressure $(\mathrm{mmHg})$ & $85.34 \pm 10.3$ & $75.5 \pm 17.8$ & $84.3 \pm 14.3$ & ns \\
\hline \multicolumn{5}{|l|}{ Renal diseases } \\
\hline Diabetic nephropathy & - & - & 10 & \\
\hline Lupus nephritis & - & 1 & - & \\
\hline Polycystic kidney disease & - & 2 & - & \\
\hline Nephroangiosclerosis & - & 7 & - & \\
\hline
\end{tabular}

Mann-Whitney U-test. ns, not significant. ${ }^{\star} P=0.048$, patients with diabetes vs. patients without diabetes and healthy subjects.

\section{Muscle oxygen consumption}

Predialysis $\mathrm{mVO}_{2}$ values were similar in the two groups of patients and in healthy subjects. The $\mathrm{mVO}_{2}$ remained unchanged in patients without diabetes during dialysis, whereas in those patients with diabetes it increased by $148.3 \%$ between predialysis and the beginning of the third hour and by $100 \%$ between predialysis and the beginning of the fourth hour (Friedman test, $P=0.002$ ) (Table 4).

\section{Oxygen supply/consumption relationship}

In patients without diabetes, the variables correlating inversely with $\mathrm{mVO}_{2}$ were $\mathrm{StO}_{2}$ and compliance (Spearman's coefficient $=-0.58, P=0.001$, and $-0.42, P=0.025$ ), whereas a direct correlation was found between $\mathrm{mVO}_{2}$ and $[\mathrm{HHb}$ (Spearman's coefficient $=-0.54, P=0.003$ ). In patients with diabetes, the only variables that correlated with $\mathrm{mVO}_{2}$ were $\mathrm{mHF}$ and mBF (Spearman's coefficient $=0.53, P=0.006$, and $0.51, P=0.004)$.

\section{Discussion}

Our results in the present in vivo study using NIRS to investigate changes in skeletal muscle oxygenation and blood flow, microvascular compliance, and $\mathrm{mVO}_{2}$ during haemodialysis provide two major findings. The first finding is that although haemodialysis left $\mathrm{StO}_{2}$ unchanged in both groups, it strongly influenced $\mathrm{Hb}$ tissue concentrations and microvascular compliance. Haemodialysis invariably caused greater changes in patients with diabetes than in those without. A second new finding in patients with diabetes was that, as well as changing tissue haemoglobin concentration and microvascular compliance, haemodialysis altered tissue blood flow ( $\mathrm{mHF}$ and $\mathrm{mBF}$ ), tissue oxygenation $\left(\mathrm{CtO}_{2}\right)$ and the metabolic rate $\left(\mathrm{mVO}_{2}\right)$. A secondary finding was that at baseline (before haemodialysis) NIRS disclosed no differences in the measured tissue variables in patients with and without diabetes, whereas in patients with diabetes the baseline values of microvascular compliance were higher than those in the healthy control group (Table 4). These findings may help to explain how haemodialysis influences muscular performance.

\section{Skeletal muscle oxygenation}

Our findings in the present study dictate two conclusions. First - at least in the patients we studied, who had no signs of cardiac or respiratory failure - dialysis leaves skeletal muscle oxygenation unchanged. Second, instead of worsening the $\mathrm{CtO}_{2}$ further, dialysis increases the oxygen content in diabetic persons and does so by increasing $\left[\mathrm{HbO}_{2}\right]$ and muscular tissue blood flow. Third, $\mathrm{CtO}_{2}$ increases during dialysis, probably because dialysis reduces factors hindering oxygen availability - in particular, the tissue water content.

Our NIRS findings showing that haemodialysis leaves skeletal muscle oxygenation unchanged argue against previous studies reporting reduced oxygenation during haemodialysis $[26,27]$.

Oxygenation during dialysis has been previously assessed in various ways and in various tissues. The data obtained in 


\begin{tabular}{|c|c|c|c|c|c|c|c|c|c|}
\hline \multirow[b]{2}{*}{ Variable } & \multirow{2}{*}{$\begin{array}{l}\text { lealthy subjects } \\
\quad(n=22)\end{array}$} & \multicolumn{4}{|c|}{ Patients without diabetes $(n=10)$} & \multicolumn{4}{|c|}{ Patients with diabetes $(n=10)$} \\
\hline & & TO & $\mathrm{T} 1$ & $\mathrm{~T} 2$ & T3 & TO & $\mathrm{T} 1$ & $\mathrm{~T} 2$ & T3 \\
\hline $\begin{array}{l}\text { Body weight } \\
(\mathrm{kg})\end{array}$ & $\begin{array}{c}76.35 \pm \\
18.34\end{array}$ & $\begin{array}{c}73.57^{\mathrm{a}} \pm \\
18.96\end{array}$ & $\begin{array}{c}71.82^{\mathrm{c}} \pm \\
17.80\end{array}$ & $\begin{array}{c}69.62 \pm \\
18.76\end{array}$ & $\begin{array}{c}68.21 \pm \\
19.51\end{array}$ & $\begin{array}{l}92.21^{\mathrm{a}} \pm \\
21.05\end{array}$ & $\begin{array}{c}90.82^{\mathrm{c}} \pm \\
25.13\end{array}$ & $\begin{array}{c}89.87 \pm \\
21.01\end{array}$ & $\begin{array}{c}88.34 \pm \\
22.98\end{array}$ \\
\hline $\begin{array}{l}\text { Mean arterial } \\
\text { pressure }(\mathrm{mmHg})\end{array}$ & - & $\begin{array}{c}93.5 \pm \\
11.1\end{array}$ & $\begin{array}{c}95.2 \pm \\
9.2\end{array}$ & $\begin{array}{c}96.2 \pm \\
7.2\end{array}$ & $\begin{array}{c}97.2 \pm \\
10.9\end{array}$ & $\begin{array}{c}98.6 \pm \\
18.5\end{array}$ & $\begin{array}{c}99.1 \pm \\
11.0\end{array}$ & $\begin{array}{c}98.4 \pm \\
13.4\end{array}$ & $\begin{array}{c}101.3 \pm \\
11.6\end{array}$ \\
\hline$[\mathrm{HbT}](\mu \mathrm{mol} / \mathrm{l})$ & $\begin{array}{c}54.18 \pm \\
19.59\end{array}$ & $\begin{array}{c}44.31^{\mathrm{a}} \pm \\
19.71\end{array}$ & $\begin{array}{c}58.24 \pm \\
18.67\end{array}$ & $\begin{array}{c}60.43 \pm \\
17.52\end{array}$ & $\begin{array}{c}62.71 \pm \\
18.32\end{array}$ & $\begin{array}{c}44.17^{\mathrm{a}} \pm \\
18.61\end{array}$ & $\begin{array}{c}60.32 \pm \\
21.10\end{array}$ & $\begin{array}{l}63.82^{b} \pm \\
24.32\end{array}$ & $\begin{array}{c}73.83 \pm \\
35.40\end{array}$ \\
\hline$[\mathrm{HHb}](\mu \mathrm{mol} / \mathrm{l})$ & $\begin{array}{c}20.44 \pm \\
9.85\end{array}$ & $\begin{array}{l}22.69^{\mathrm{a}} \pm \\
16.10\end{array}$ & $\begin{array}{c}31.37 \pm \\
17.82\end{array}$ & $\begin{array}{c}32.83 \pm \\
18.43\end{array}$ & $\begin{array}{c}35.92 \pm \\
19.23\end{array}$ & $\begin{array}{c}21.86^{\mathrm{a}} \pm \\
10.34\end{array}$ & $\begin{array}{c}30.34 \pm \\
11.32\end{array}$ & $\begin{array}{l}32.75 \pm \\
11.23\end{array}$ & $\begin{array}{c}35.84 \pm \\
14.07\end{array}$ \\
\hline$\left[\mathrm{HbO}_{2}\right](\mu \mathrm{mol} / \mathrm{l})$ & $\begin{array}{l}33.74^{\mathrm{e}} \pm \\
14.17\end{array}$ & $\begin{array}{c}21.62 \pm \\
11.67\end{array}$ & $\begin{array}{c}26.87 \pm \\
11.34\end{array}$ & $\begin{array}{l}27.60 \pm \\
10.43\end{array}$ & $\begin{array}{c}26.79 \pm \\
12.32\end{array}$ & $\begin{array}{c}22.31^{a} \pm \\
11.86\end{array}$ & $\begin{array}{l}29.98 \pm \\
13.45\end{array}$ & $\begin{array}{c}31.07 \pm \\
14.54\end{array}$ & $\begin{array}{c}37.99 \pm \\
18.54\end{array}$ \\
\hline $\begin{array}{l}\mathrm{CtO}_{2}(\mathrm{ml} \mathrm{O} / \\
100 \mathrm{ml})\end{array}$ & $\begin{array}{c}0.29^{\mathrm{e}} \pm \\
0.12\end{array}$ & $\begin{array}{l}0.18 \pm \\
0.13\end{array}$ & $\begin{array}{l}0.23 \pm \\
0.08\end{array}$ & $\begin{array}{c}0.20 \pm \\
0.14\end{array}$ & $\begin{array}{c}0.21 \pm \\
0.11\end{array}$ & $\begin{array}{c}0.19^{\mathrm{a}} \pm \\
0.09\end{array}$ & $\begin{array}{c}0.24 \pm \\
0.10\end{array}$ & $\begin{array}{c}0.26^{\mathrm{b}} \pm \\
0.09\end{array}$ & $\begin{array}{c}0.32 \pm \\
0.11\end{array}$ \\
\hline $\begin{array}{l}\text { Microvascular } \\
\text { compliance } \\
(\mathrm{ml} / \mathrm{mmHg} / 100 \mathrm{ml})\end{array}$ & $\begin{array}{c}0.11^{\mathrm{e}} \pm \\
0.12\end{array}$ & $\begin{array}{l}0.161^{\mathrm{a}} \pm \\
0.110\end{array}$ & $\begin{array}{c}0.061^{\mathrm{c}} \pm \\
0.041\end{array}$ & $\begin{array}{l}0.010 \pm \\
0.010\end{array}$ & $\begin{array}{l}0.006 \pm \\
0.001\end{array}$ & $\begin{array}{l}0.221^{\mathrm{a}} \pm \\
0.140\end{array}$ & $\begin{array}{l}0.045 \pm \\
0.051\end{array}$ & $\begin{array}{l}0.019 \pm \\
0.015\end{array}$ & $\begin{array}{c}0.013 \pm \\
0.010\end{array}$ \\
\hline $\mathrm{StO}_{2}(\%)$ & $\begin{array}{c}62.3 \pm \\
7.3\end{array}$ & $\begin{array}{c}51.5 \pm \\
21.4\end{array}$ & $\begin{array}{c}50.3 \pm \\
19.9\end{array}$ & $\begin{array}{c}49.1 \pm \\
22.9\end{array}$ & $\begin{array}{c}46.1 \pm \\
21.3\end{array}$ & $\begin{array}{c}49.1 \pm \\
16.6\end{array}$ & $\begin{array}{c}47.9 \pm \\
13.4\end{array}$ & $\begin{array}{c}48.7 \pm \\
12.8\end{array}$ & $\begin{array}{c}50.3 \pm \\
12.3\end{array}$ \\
\hline $\begin{array}{l}\mathrm{mHF}(\mu \mathrm{mol} / \mathrm{min} / \\
100 \mathrm{ml})\end{array}$ & - & $\begin{array}{c}1.81 \pm \\
1.21\end{array}$ & $\begin{array}{c}1.74 \pm \\
0.98\end{array}$ & $\begin{array}{c}2.52 \pm \\
1.61\end{array}$ & $\begin{array}{c}1.64 \pm \\
0.89\end{array}$ & $\begin{array}{c}1.76^{c} \pm \\
0.82\end{array}$ & $\begin{array}{c}2.10 \pm \\
0.74\end{array}$ & $\begin{array}{c}3.15 \pm \\
1.01\end{array}$ & $\begin{array}{c}3.11 \pm \\
1.52\end{array}$ \\
\hline $\begin{array}{l}\mathrm{mBF}(\mathrm{ml} / \mathrm{min} / \\
100 \mathrm{ml})\end{array}$ & $\begin{array}{c}4.01 \pm \\
1.98\end{array}$ & $\begin{array}{c}3.12 \pm \\
2.12\end{array}$ & $\begin{array}{l}3.121 \pm \\
1.55\end{array}$ & $\begin{array}{c}4.33 \pm \\
2.75\end{array}$ & $\begin{array}{c}2.83 \pm \\
1.54\end{array}$ & $\begin{array}{c}3.02^{d} \pm \\
1.78\end{array}$ & $\begin{array}{c}3.76 \pm \\
1.32\end{array}$ & $\begin{array}{c}5.42 \pm \\
1.73\end{array}$ & $\begin{array}{c}5.03 \pm \\
2.41\end{array}$ \\
\hline $\begin{array}{l}\mathrm{mVO}_{2}(\mathrm{ml} / \mathrm{min} / \\
100 \mathrm{ml})\end{array}$ & $\begin{array}{c}0.23 \pm \\
0.13\end{array}$ & $\begin{array}{l}0.34 \pm \\
0.27\end{array}$ & $\begin{array}{l}0.35 \pm \\
0.15\end{array}$ & $\begin{array}{l}0.42 \pm \\
0.22\end{array}$ & $\begin{array}{c}0.36 \pm \\
0.12\end{array}$ & $\begin{array}{c}0.29^{c} \pm \\
0.15\end{array}$ & $\begin{array}{c}0.41^{d} \pm \\
0.13\end{array}$ & $\begin{array}{c}0.72 \pm \\
0.21\end{array}$ & $\begin{array}{c}0.58 \pm \\
0.20\end{array}$ \\
\hline
\end{tabular}

$[\mathrm{HbT}]$, total haemoglobin concentration; $[\mathrm{HHb}]$, deoxygenated haemoglobin concentration; $\left[\mathrm{HbO}_{2}\right]$, oxygenated haemoglobin concentration; $\mathrm{CtO}_{2}$, tissue oxygen content; $\mathrm{StO}_{2}$, tissue oxygen saturation; $\mathrm{mHF}$, muscular haemoglobin flow; $\mathrm{mBF}$, muscular blood flow; mVO $\mathrm{O}_{2}$, muscle oxygen consumption. Wilcoxon test: a $P<0.05$ vs. beginning of the second hour (T1), beginning of the third hour (T2), beginning of the fourth hour (T3); b $P<0.05$ vs. T3; ${ }^{c} P<0.05$ vs. T2, T3; ${ }^{d} P<0.05$ vs. T2. Mann-Whitney $\mathrm{U}$ test: ${ }^{e} P<0.05$ vs. predialysis (T0) of patients with diabetes.

humans with transcutaneous partial pressure of oxygen monitoring [27] show that oxygenation falls dramatically during dialysis and remains low for at least 4 hours thereafter. Previous studies also reported a 5 to $15 \%$ fall in the partial pressure of oxygen in arterial blood within about 30 to 60 minutes after dialysis began that persisted throughout the session [28]. The measurements of the oxygen tension could be influenced by the acetate in the dialysis fluid, or by the patients' cardiopulmonary status [29], or by both. Although to avoid arterial cannulation in patients attending the daycare clinic we did not obtain serial measurements of the partial pressure of oxygen in arterial blood, neither of these factors influenced our results because our patients were dialyzed with bicarbonate fluid and we excluded patients who had signs of cardiac or respiratory failure. Furthermore, the discrepancy between the oxygen tension measurements and the $\mathrm{Hb}$ oxygenation rate measured by NIRS can be fully explained considering that these variables reflect different types of oxygenation differently affected by fluid removal.
The absence of differences between the studied variables in the two groups of patients could depend on the small study sample and the higher variability in patients without diabetes than in those with diabetes. Unlike other studies, we measured absolute skeletal muscle oxygenation during dialysis non-invasively in patients at rest. Predialysis tissue oxygen content $\mathrm{HbO}_{2}$ and $\mathrm{CtO}_{2}$ values were nevertheless lower in patients with diabetes than in healthy subjects, and dialysis for 1 hour was sufficient to annul the difference.

Previous data obtained with NIRS technology already document higher $\mathrm{Hb}$ desaturation in patients with peripheral vascular disease and diabetes during exercise [30]. In theory, the reduced baseline skeletal muscle oxygenation $\left(\mathrm{HbO}_{2}, \mathrm{StO}_{2}\right.$ and $\mathrm{CtO}_{2}$ ) we detected in patients with diabetes at rest could be related to the microangiopathy typical of diabetes [31].

The reduced oxygenated $\mathrm{Hb}$ concentration shown in both groups of patients could reflect the lower arteriolar and 
capillary vascular compared with the venular bed. These microvascular changes reverse during haemodialysis (Table 4).

Even though $\mathrm{StO}_{2}$ predialysis values were lower in patients with diabetes than in healthy controls, haemodialysis left $\mathrm{StO}_{2}$ unchanged in both groups of patients studied. The absence of changes in $\mathrm{StO}_{2}$ despite marked changes in tissue [HbT], $[\mathrm{HHb}]$ and $\left[\mathrm{HbO}_{2}\right]$ - reflecting changes in the vascular bed, blood flow and $\mathrm{mVO}_{2}$ - confirms that $\mathrm{StO}_{2}$ (percentage tissue oxygenation) is not merely a variable indicating the balance between blood flow and oxygen extraction. $\mathrm{StO}_{2}$ depends critically on the tissue vascular bed, whose volumes vary substantially under healthy and pathological conditions [32].

Our NIRS findings also extend current knowledge on the in vivo dialysis-induced changes in the skeletal muscle blood flow. Ample research on systemic haemodynamics during haemodialysis already shows, even in haemodynamically stable subjects, a reduction in cardiac output and oxygen supply, and indirectly an increase in systemic vascular resistance [14]. These systemic changes led the investigators to conclude that haemodialysis induces peripheral hypoperfusion [33].

Although we cannot compare our findings in patients with diabetes and studies investigating other groups of patients, the increased calf blood flow that NIRS documented in our patients without diabetes seemingly contrast with microneurographic data on the increased sympathetic activity [34].

A possible reason for this discrepancy is that dialysis increases the $[\mathrm{HHb}]$ and $\left[\mathrm{HbO}_{2}\right]$ variables, reflecting changes in the numbers of capillaries, arteriovenous shunts, postcapillary venules and, to a lesser extent, the arterioles [35]. These vascular bed changes might in theory be accompanied by increased neuronal sympathetic activity that could leave overall local tissue blood flow unchanged.

\section{Microvascular bed}

A finding that extends current knowledge on the in vivo effects of haemodialysis was that the volume and distribution of the microvascular bed increased in both groups of dialyzed patients. Our data corrected for vascular $\mathrm{Hb}$ changes (Table 2) exclude the possibility that $\mathrm{Hb}$ concentrations increase because dialysis removes excess fluid within vessels, and suggest that dialysis removes body fluids outside the vessels, thus reducing interstitial oedema [36], and at the same time reduces external compression on the microcirculation. Vasodilation could also arise from dialysisinduced inflammation through complement factor activation and vascular endothelial production of cytokines and prostacyclin [37].

Another reason for vasodilation is that many of our subjects were taking vasoactive drugs. Calcium antagonists, angiotensin-converting enzyme inhibitors, and $\alpha$-antagonists might therefore have helped to amplify the response to dialysisinduced fluid removal, especially given that patients taking these agents were mostly diabetic individuals. Even though we excluded patients who had a history of autonomic nervous system dysfunction or experienced hypotensive episodes during dialysis, we cannot exclude the possibility that the abnormal vasodilation especially in patients with diabetes depended on autonomic dysregulation. Neither autonomic dysfunction nor medications nevertheless brought about a reduction in arterial pressures that could have distinguished between the two study groups.

\section{Microvascular compliance}

The mechanism through which haemodialysis reduced microvascular compliance in our patients remains unclear. A possible explanation is that it depends on microvascular dilation, as we suggested in an earlier paper [10]. This hypothesis agrees with the $[\mathrm{HHb}]$ increase we observed in the present study presumably reflecting venous dilation strong enough to reduce compliance. The role of dialysis could be to reduce external compression on the microvascular bed, thus allowing the bed to expand.

\section{Muscle oxygen consumption}

In our study we found no differences in $\mathrm{mVO}_{2}$ before dialysis either between the two groups of patients or between the patients and healthy controls. The reduced number of muscle fibres in patients with chronic renal failure [1] presumably therefore has no effect on oxygen consumption in skeletal muscle at rest. The absence of changes in $\mathrm{mVO}_{2}$ agrees with the unchanged baseline metabolism in patients undergoing chronic dialysis [32,38].

\section{Oxygen supply/consumption relationship}

Even though haemodialysis increased tissue $[\mathrm{HHb}]$ and reduced microvascular compliance in both groups of patients studied, only in those patients with diabetes did dialysis lead to increased blood flow, $\mathrm{HbO}_{2}, \mathrm{CtO}_{2}$ and $\mathrm{mVO}_{2}$. The increased blood flow was presumably due to the augmented arteriolar and capillary bed. Because we studied patients at rest, the increased oxygen availability was presumably not the consequence but the cause of the increased muscle-tissue metabolic rate.

Our NIRS findings on the tissue effects induced by haemodialysis in patients with diabetes also provide useful information on the relationship between oxygen consumption and supply. An interesting finding was that even though dialysis left $\mathrm{StO}_{2}$ statistically unchanged, the increased cell metabolism was correlated to the increase of blood supply. In our study, we observed no changes in oxygen supply other than those related to the dialytic therapy itself - showing that, in the skeletal muscle of diabetic patients with chronic renal failure at rest, dialysis reverses the $\mathrm{mVO}_{2}$ limited by blood flow supply. Why we found a relationship between blood flow and oxygen consumption only in diabetic subjects remains to be clarified. 
Although dialysis was not shown to modify cell metabolism in patients without diabetes, the correlation between, on one hand, the reduced microvascular compliance and, on the other hand, the deoxygenated $\mathrm{Hb}$ tissue concentration and the increased tissue oxygen consumption seems to confirm the role of fluid removal during dialysis [39] as a factor facilitating cell metabolism.

\section{Limitations}

Our study has several limitations. First, none of our patients underwent specific testing to evaluate autonomic system function. We nevertheless considered it sufficient for the purposes of this study to exclude subjects who had clinical signs of autonomic dysfunction.

Second, as other researchers have underlined, subcutaneous fat interferes with NIRS signals [19]. Although most of the diabetic patients we studied were heavier than the nondiabetic subjects, the device we used in the previous study uses a specific algorithm to correct for signal interference normally caused by adipose tissue. As we previously observed [40], this algorithm corrects the measured values for interference from adipose tissue. Even though our patients with diabetes were generally heavier than the patients without diabetes and the healthy controls, we found no difference in skinfold measures. They may nevertheless have had a higher water content or more fat, or both, within skeletal muscle [41].

A possible technical limitation is that the changes in the microvascular bed we describe are indirectly derived from changes in tissue $\mathrm{Hb}$ concentrations detected by NIRS. Unfortunately, we cannot compare our results with those from an in vivo reference technique measuring tissue $\mathrm{Hb}$ because no such standard exists.

Finally, another possible limitation of the study is that the small patient numbers might have prevented us from detecting eventual differences ( $\beta$ error). Our strict enrolment criteria nevertheless prevented us from enrolling a larger number of patients during the 2-month enrolment period.

\section{Conclusions}

Our NIRS findings suggest that haemodialysis in subjects at rest brings about major changes in skeletal muscle oxygenation and blood flow, microvascular compliance and tissue metabolic rate. These changes differ in patients without and with diabetes. In both groups of patients, haemodialysis induces changes in tissue $\mathrm{Hb}$ concentrations and microvascular compliance. Conversely, in those patients with diabetes, haemodialysis also alters tissue blood flow ( $\mathrm{mHF}$ and $\mathrm{mBF})$, tissue oxygenation $\left(\mathrm{CtO}_{2},\left[\mathrm{HbO}_{2}\right]\right)$ and the metabolic rate $\left(\mathrm{mVO}_{2}\right)$.

\section{Competing interests}

The authors declare that they have no competing interests.

\section{Acknowledgement}

This article is part of Critical Care Volume 13 Supplement 5: Tissue oxygenation $\left(\mathrm{StO}_{2}\right)$ in healthy volunteers and critically-ill patients. The full contents of the supplement are available online at http://ccforum. com/supplements/13/S5. Publication of the supplement has been supported with funding from Hutchinson Technology Inc.

\section{References}

1. Kemp GJ, Crowe AV, Anijeet HK, Gong QY, Bimson WE, Frostick SP, Bone JM, Bell GM, Roberts JN: Abnormal mitochondrial function and muscle wasting, but normal contractile efficiency, in haemodialysed patients studied non-invasively in vivo. Nephrol Dial Transplant 2004, 19:1520-1527.

2. Kouidi E, Albani M, Natsis K, Megalopoulos A, Gigis P, GuibaTziampiri O, Tourkantonis A, Deligiannis A: The effects of exercise training on muscle atrophy in haemodialysis patients. Nephrol Dial Transplant 1998, 13:685-699.

3. Brodin E, Ljungman S, Hedberg M, Sunnerhagen KS: Physical activity, muscle performance and quality of life in patients treated with chronic peritoneal dialysis. Scand J Urol Nephrol 2001, 35:71-78.

4. Sietsema KE, Amato A, Adler SG, Brass EP: Exercise capacity as a predictor of survival among ambulatory patients with ESRD. Kidney Int 2004, 65:719-724.

5. Johansen KL: Physical functioning and exercise capacity in patients on dyalisis. Adv Ren Replace Ther 1999, 6:141-148.

6. Pannier B, Guerin AP, Marchais SJ, Metivier F, Safar ME, London GM: Postischemic vasodilation, endothelial activation and cardiovascular remodelling in end-stage renal disease. Kidney Int 2000, 57:1091-1099.

7. London GM, Pannier B, Agharazii M, Guerin AP, Verbke FH, Marchais SJ: Forearm reactive hyperemia and mortalità in endstage renal disease. Kidney Int 2004, 65:700-704.

8. Passauer J, Pistrosch F, Büssemaker E, Lässig G, Herbrig K, Gross P: Reduced agonist-induced endothelium-dependent vasodilation in uremia is attributable to an impairment of vascular nitric oxide. J Am Soc Nephro/ 2005, 16:959-965.

9. Marrades RM, Roca J, Campistol JM, Diaz O, Barberá JA, Torregrosa JV, Masclans JR, Cobos A, Rodríguez-Roisin R, Wagner PD: Effects of erythropoietin on muscle $\mathrm{O}_{2}$ transport during exercise in patients with chronic renal failure. J Clin Invest 1996, 97:2092-2100.

10. De Blasi RA, Palmisani S, Alampi D, Mercieri M, Romano R, Collini S, Pinto G: Microvascular dysfunction and skeletal muscle oxygenation assessed by phase-modulation near-infrared spectroscopy in patients with septic shock. Intensive Care Med 2005, 31:1661-1668.

11. Schalkwijk CG, Stehouwer CD: Vascular complications in diabetes mellitus: the role of endothelial dysfunction. Clin Sci (Lond) 2005, 109:143-159.

12. Morbach S, Quante C, Ochs HR, Gaschler F, Pallast J-M, Knevels $\mathrm{U}$ : Increased risk of lower-extremity amputation among Caucasian diabetic patients on dialysis. Diabetes Care 2001, 24: 1689-1670.

13. McGrath NM, Curran BA: Recent commencement of dialysis is a risk factor for lower-extremity amputation in a high-risk diabetic population. Diabetes Care 2000, 23:432-433.

14. Bos WJW, Buin Sjoerd, van Older RW, Keur I, Wesseling KH, Westerhof N, Krediet RT, Aritsz LA: Cardiac and hemodynamic effects of hemodialysis and ultrafiltration. $A m J$ Kidney Dis 2000, 35:819-826.

15. Converse RL, Jacobsen TN, Fouad-Tarazi F, Obregon TM, Toto RD, Victor RG: Paradoxical withdrawal of reflex vasoconstriction as a cause of hemodialysis-induced hypotension. J Clin Invest 1992, 90:1657-1665.

16. van der Sande FM, Kooman JP, van Kuijk WHM, Leunissen KML: Management of hypotension in dialysis patients: role of dialysate temperature control. Saudi J Kidney Dis Transplant 2001, 12:328-386.

17. Rovati L, Bandera A, Donini M, Salvatori G: Design and performance of a wide-bandwidth and sensitive instrument for near-infrared spectroscopic measurements on human tissue. Rev Sci Instrum 2004, 75:5315-5325.

18. Matcher S, Cope M, Delpy D: Use of the water absorption spectrum to quantify tissue chromophore concentration changes in near infrared spectroscopy. Phys Med Biol 1993, 38:177-196. 
19. Van Beekvelt M, Borghuis M, Van Engelen B, Wevers R, Collier $\mathrm{W}$ : Adipose tissue thickness affects in vivo quantitative nearIR spectroscopy in human skeletal muscle. Clin Sci (Lond) 2001, 101:21-28.

20. Martelli F, Del Bianco S, Zaccanti G: Effect of the refractive index mismatch on light propagation through diffusive layered media. Phys Rev E Stat Nonlin Soft Matter Phys 2004, 70:011907.

21. Simpson CR, Kohl M, Essenpreis M, Cope M: Near-infrared optical properties of ex vivo human skin and subcutaneous tissues measured using the Monte Carlo inversion technique. Phys Med Biol 1998, 43:2465-2478.

22. Castaneda-Sceppa C, Sarnak MJ, Wang X, Greene T, Madero M, Kusek JW, Beck G, Kopple JD, Levey AS, Menon V: Role of adipose tissue in determining muscle mass in patients with chronic kidney disease. J Renal Nutr 2007, 17:314-322.

23. Klitzman B, Duling BR: Microvascular hematocrit and red cell flow in resting and contracting striated muscle. Am J Physiol 1979, 237: H481-H490.

24. De Blasi RA, Ferrari M, Natali A, Conti G, Mega A, Gasparetto A: Noninvasive measurement of forearm blood flow and oxygen consumption by near-infrared spectroscopy. J Appl Physiol 1994, 76:1388-1393.

25. Wolf U, Wolf M, Choi JH, Levi M, Choudhury D, Hull S, Coussirat D, Paunescu LA, Safonova LP, Michalos A, Mantulin WW, Gratton E: Localized irregularities in haemoglobin flow and oxygenation in calf muscle in patients with peripheral vascular disease detected with near-infrared spectrophotometry. J Vasc Surg 2003, 37:1017-1026.

26. Weiss T, Windthorst C, Weiss C, Kreuzer J, Bomber J, Kübler W: Acute effects of haemodialysis on cutaneous microcirculation in patients with peripheral arterial occlusive disease. Nephrol Dial Transplant 1998, 13:2317-2321.

27. Hinchliffe RJ, Kirk B, Bhattacharjee D, Roe S, Jeffcoate W, Game $F$ : The effect of haemodialysis on transcutaneous oxygen tension in patients with diabetes - a pilot study. Nephrol Dial Transplant 2006, 21:1981-1983.

28. Abu-Hamdan DK, Desai SG, Mahajan SK, Muller BF, Briggs WA, Lynne-Davies P, McDonald FD: Hypoxemia during haemodialysis using acetate versus bicarbonate dialysate. $\mathrm{Am} J \mathrm{Nephrol}$ 1984, 4:248-253.

29. Pitcher WD, Diamond SM, Henrich WL: Pulmonary gas exchange during dialysis in patients with obstructive lung disease. Chest 1989, 96:1136-1141.

30. Hamaoka T, McCully KK, Quaresima V, Yamamoto K, Chance B: Near-infrared spectroscopy/imaging for monitoring muscle oxygenation and oxidative metabolism in healthy and diseased humans. J Biomed Opt 2007, 12:62105.

31. Rooke TW, Osmundson PJ: The influence of age, sex, smoking, and diabetes on lower limb transcutaneous oxygen tension in patients with arterial occlusive disease. Arch Intern Med 1990, 150:129-132.

32. Sala E, Noyszewski EA, Campistol JM, Marrades RM, Dreha S, Torregrossa JV, Beers JS, Wagner PD, Roca J: Impaired muscle oxygen transfer in patients with chronic renal failure. $A m$ Physiol Regul Integr Comp Physiol 2001, 280:R1240-R1248.

33. Schneditz D, Zaluska WT, Morris AT, Levin NW: Effects of ultrafiltration on peripheral urea sequestration in haemodialysis patients. Nephrol Dial Transplant 2001, 16:994-998.

34. Hansen J, Victor RG: Direct measurement of sympathetic activity: new insights into disordered blood pressure regulation an chronic renal failure. Curr Opin Nephrol Hypertens 1994, 3:636-643.

35. Mancini DM, Bolinger L, Li H Kendrick, Chance B, Wilson JR: Validation of near infrared spectroscopy in humans. J Appl Physiol 1994, 77:2740-2747.

36. Movilli E, Cancarini GC, Cassamali S, Camerini C, Brunori G, Maffei $C$, Maiorca R: Inter dialytic variations in blood volume and total body water in uraemic patients treated by dialysis. Nephrol Dial Transplant 2004, 19:185-189.

37. Jofré R, Rodriguez-Benitez P, López-Gómez JM, Pérez-Garcia R: Inflammatory syndrome in patients on haemodialysis. $J \mathrm{Am}$ Soc Nephrol 2006, 17:274-280.

38. Kamimura MA, Draibe SA, Avesani CM, Canziani MEF, Colugnani FAB, Cuppari L: Resting energy expenditure and its determinants in haemodialysis patients. Eur J Clin Nutr 2007, 61:362367.
39. Minutolo R, De Nicola L, Bellizzi V, lodice C, Rubino R, Aucella F, Stallone C, Nappi F, Avella F, Maione E, Conte G, Di lorio BR: Intra- and post-dialytic changes of haemoglobin concentrations in non-anaemic haemodialysis patients. Nephrol Dial Transplant 2003, 18:2606-2612.

40. De Blasi RA, Palmisani S, Boezi M, Arcioni R, Collini S, Troisi F, Pinto G: Effects of remifentanil-based general anaesthesia with propofol or sevoflurane on muscle microcirculation as assessed by near-infrared spectroscopy. Br J Anesth 2008, 101:171-177.

41. Perseghin G, Scifo P, De Cobelli F, Pagliato E, Battezzati A, ArcelIoni C, Vanzulli A, Testolin G, Pozza G, Del Maschio A, Luzi L: Intramyocellular triglyceride content is a determinant of in vivo insulin resistance in humans: a ${ }^{1} \mathrm{H}-{ }^{13} \mathrm{C}$ nuclear magnetic resonance spectroscopy assessment in offspring of type 2 diabetic parents. Diabetes 1999, 48:1600-1606. 